\title{
Self-Regulation Effects on Smoking Addiction: A Bayesian Approach*
}

\section{Efectos de la autorregulación sobre la adicción al tabaco: un enfoque bayesiano}

Received: 15 November 2017 | Accepted: 29 November 2020

\author{
AfiQ W. Muhammad \\ Universitas Gadjah Mada, Indonesia \\ ORCID: https://orcid.org/0000-0001-7170-0547 \\ BHINA PATRIA ${ }^{\mathrm{a}}$ \\ Universitas Gadjah Mada, Indonesia \\ ORCID: https://orcid.org/0000-0003-1419-4240
}

a Correspondence author. Email: patria@ugm.ac.id

How to cite: Muhammad, A., \& Patria, B. (2021). Selfregulation effects on smoking addiction: A bayesian approach. Universitas Psychologica, 20, 1-10. https://doi.org/10.11144/ Javeriana.upsy20.sres

\begin{abstract}
This study aimed to determine the impacts of self-regulation on smoking addiction. Self-regulation is the capacity to overcome ineffective behavior to achieve goals. Previous research studies found that self-regulation is an effective mental defense against deviant behaviors such as smoking. This study hypothesized that self-regulation correlates negatively with smoking addiction. The subjects in this study were 155 students aged $13-18$ years $(M=13.37, S D=1.07)$ from three high schools in Sleman district, Yogyakarta, Indonesia. The data were analysed with Bayesian regression and simple linear regression as a comparison. The Bayesian regression showed that $95 \%$ posterior distribution HDI falls outside ROPE (-0.5-0). The results indicated that self-regulation has significant effects on reducing smoking addiction. Additionally, the simple linear regression also showed similar results $(F(1.153)=82.12, p<0.01)$. The generalizability of the results is only limited to the sample being used in this study.

Keywords

smoking addiction; self-regulation; Bayesian regression; smoking; Bayesian inference.
\end{abstract}

\section{RESUMEN}

Este estudio tiene como objetivo determinar el impacto de la autorregulación en la adicción al tabaco. La autorregulación es la capacidad de superar el comportamiento ineficaz para alcanzar los objetivos. Investigaciones previas encontraron que la autorregulación es una defensa mental efectiva contra conductas desviadas como fumar. La hipótesis de este estudio fue que la autorregulación se correlaciona negativamente con la adicción al tabaco. Los sujetos de estudio fueron 155 de entre 13 y 18 años $(M=13.37, S D=1.07)$ estudiantes de tres escuelas secundarias en el distrito de Sleman, Yogyakarta, Indonesia. Los datos se analizaron mediante una regresión bayesiana y una regresión lineal simple como comparación. La regresión bayesiana mostró que el 95\% de la distribución a posteriori HDI cae fuera de la ROPE (-0.5-0). Los resultados indicaron que la autorregulación tiene efectos significativos en la reducción de la adicción al tabaco. Además, la regresión lineal simple también mostró resultados similares $(F(1.153)=82.12, p<0.01)$. 
Palabras clave

adicción al cigarrillo; autorregulación; regresión bayesiana; fumar; inferencia bayesiana.

Among Indonesian adolescence, the smoking prevention program failed to attain its purposes. The 2014 survey showed that Indonesia was one of the largest adolescent smokers in Asia, with $20 \%$ of its adolescent (age 13-19) smokers. By gender, the rate is $36 \%$ in males and $4 \%$ in females (WHO, 2015). Furthermore, the data depicted that $32.1 \%$ of students smoked any tobacco product at least once in their lifetime. The number is increasing compared to five years earlier which was 30.4\% (WHO, 2015).

Ogden (2005) defines an addict as a person who cannot resist temptation. The temptation causes many compulsive behaviors, such as repeatedly consuming a substance (e.g., alcohol, nicotine, and heroin) or continuously engaging in a specific activity (e.g., gaming, gambling, and eating). This addictive behavior is caused by specific stimulants that flooded the brain with dopamine and constructed a pleasurable memory associated with rewarding sensation (Schmidt et al., 2018). Smoking addicts have difficulties when trying to stop because they have associated smoking with pleasure. There are two types of Adolescence smoking addictions, behavioral addiction and physiological addiction (Deolia et al., 2018). Physiological addiction, also called biological addiction, was caused merely by the substances in cigarettes (i.e., nicotine) (Carey $\&$ Wilkinson, 2016). The main attributes of this addiction type are the presence of tolerance and withdrawal. On the other hand, behavioral addiction is caused by anything but substance effects (e.g., A teenager smoke because he values the smoking process as an enjoyable moment). Besides substance effects, smoking addiction is also influenced by social life, such as peer-group, neighborhood (Liu et al., 2017; Robalino \& Macy, 2018), and personality (Abe et al., 2019; Choi et al., 2017).

Smoking causes many adverse effects on adolescents. Robert et al. (2019) stated a negative correlation between smoking behaviors and students' achievement in school since smoking might affect daily activities. Other research conducted by Ribeiro et al. (2013) also found smoking caused the delay in school activity and further addiction problem such as alcohol use. For example, when smokers crave a cigarette, they might experience concentration difficulties, anxiety, insomnia, and increasing appetite (Ranjit et al., 2019). Another research found that smoking is one of the risk factors for coronary disease (Farmawati et al., 2017). A teenager who smokes also has an increased risk factor of later mortality, such as cardiovascular disease (Khan et al., 2015). Although smoking had proved to cause harm, the smoking rate in Indonesian adolescence has not yet decreased. This means that there is an urgent need to tackle the smoking problem. Hence, the current study assessed whether self-regulation has an impact on adolescent smoking behavior.

Self-regulation has an important role in managing one's behaviors (Berkman, 2016). Selfregulation is categorized as basic social skills because it is associated with emotional control, cognitive and social development (Eisenberg et al., 2016). Developing self-regulation skills is important for adolescents since it becomes a mental defense and prevents deviant behavior (Billen et al., 2020). In addition, there is also selfregulation failure, which is divided into failures of under regulation and misregulation (Sayette $\&$ Creswell, 2016). Many juvenile delinquencies (Baumeister et al., 1994), and addictive behavior such as smoking (Evans et al., 2018), are caused by self-regulation failures. Self-regulation also plays a role in smoking cessation; its absence makes cessation more difficult for a smoker to cease (Daly et al., 2015). The research found that in the cessation process, a smoker whom a therapist helps to regain self-regulation tends to resist smoking relapse (Hatzigeorgiadis et al., 2016). 


\section{Method}

\section{Participant}

One hundred and fifty-five male high school students were recruited for this study. Only $13-18$ years old students $(M=13.37, S D=1.07)$ were included in the study. The participant was selected from three different high schools in Sleman district, Yogyakarta, Indonesia. The selection used a purposive sampling method (Barreiro \& Albandoz, 2001). The participation was voluntary, and all participants filled the informed consent form before filling the questionnaire.

\section{Material}

A survey study approach was chosen to gather data from subjects. The data were collected using two instruments. First, the selfregulation scale developed upon five aspects: selection, monitoring, evaluation, motivation, and inhibition. (1) Selection is an individual ability to identify his strength, set a goal, plan, and direct his strength to achieve his goal (Baltes, 1997; Barkley, 2012; Baumeister \& Vohs, 2007; Zimmerman, 2000). (2) Monitoring is defined as the capacity to self-supervise his action or behavior, whether still on track or there is a deviation from the goal he set (Baltes, 1997; Barkley, 2012; Baumeister \& Vohs, 2007; Zimmerman, 2000). (3) Evaluation; Self-adjustment ability to adapt his behavior, when someone finds any discrepancy in current activities, responds by reducing the gap between current action and his goals (Baltes, 1997; Barkley, 2012; Baumeister \& Vohs, 2007; Zimmerman, 2000). (4) Motivation; Individual diligence and continuity to complete his work and achieve goals (Baumeister \& Vohs, 2007). (5) Inhibition; Individual resistance from impulsive temptations and make an action even when it is undesirable (Barkley, 1997, 2001).

The second instrument was the smoking addiction scale developed based on four aspects of behavioral addiction and two aspects of substance addiction. The two aspects of substance addiction were adapted from the Fagerstrom Test for Nicotine Dependence (FTND) (Heatherton et al., 1991). The two aspects are (1) time to first cigarette (i.e., the duration between wake-up time and the first cigarette); and (2) the average of daily cigarette consumption. The other four aspects of behavioral dependence were: smoking in certain social situations, cope with situations of varying degrees of stress, salience, and conflict. (1) Smoking with certain social situations; this aspect measure how far the social environment influence the emergence of smoking. According to Schane et al. (2009), a social situation can encourage smoking behavior without any sign of substance addiction. (2) Cope with varying degrees of stress; Smoking behavior is used as a coping strategy when experiencing emotional stress and negative mood (Griffiths, 2005; Rosenberg \& Feder, 2014). (3) Salience; occurs when someone appraises high on smoking activity; smoking becomes important for him and dominates most of his thoughts, feelings, and activities (Griffiths, 2005; Rosenberg \& Feder, 2014). (4) Conflict; the harmful effects caused by the continuity of smoking behavior. These effects resulted from smoking discrepancy to another activity, other people surroundings, and smokers themselves as personal (Griffiths, 2005; Rosenberg \& Feder, 2014).

Both scales were designed using a five-point Likert scale. The results of internal reliability test were $\alpha=0.893(n=86)$ for self-regulation scale, and $\alpha=0.935(n=86)$ for smoking addiction. This result shows that both scales have a good reliability coefficient. According to Wells \& Wollack (2003), the proper reliability coefficient for a non-high-risk measure instrument is $>0.85$.

\section{Analysis method}

The data were analyzed using Bayesian regression and linear regression. Although its simplicity and robustness, Wagenmakers (2007) argued that the regression formula could not guarantee statistical evidence because the sample size easily influences 
its p-value. Meanwhile, the Bayesian formula does not require a large sample size. Previous studies showed that the Bayesian approach could process small data set with higher accuracy (van de Schoot \& Depaoli, 2014; Zhang et al., 2007). One of the advantages of Bayesian is that it produces posterior distribution from the simulation chain of the prior distribution and considers probability from both null hypotheses and alternative hypotheses (Jarosz \& Wiley, 2014). This method's result cam also also can be interpreted as a probability, while frequentist regression's interpretation is limited to the prediction of replication result. For example, the Bayesian approach may conclude that the probability of regression coefficient lie within some point is $95 \%$. Despite the advantages, a few psychological research studies used Bayesian (van de Schoot \& Depaoli, 2014).

\section{Results}

\section{Bayesian regression}

The data were estimated using BEST or Bayesian estimation constructed by Kruschke (2015), namely Jags-Ymet-Xmet-Mrobust. There is some advantage of using Stan; first, it uses efficient sampling algorithms (Kruschke, 2015). Second, it is open-source hence can be run into various programs such as R, Python, Matlab, and Stata (Baldwin \& Larson, 2016). The Bayesian analysis regression model is presented below:

$$
y \sim \beta 0+\beta 1 * x, \Sigma
$$

Normal distribution was chosen for prior distribution. After Markov Chain Monte Carlo (MCMC) simulation using Stan feature, posterior distribution was acquired. The MCMC simulation burned 5000 iterations in four chains and showed convergence. The convergence of the chain showing that the tested sample was actually drawn from the posterior distribution (Kruschke, 2015). Convergence achievement is shown by Figure 1, the upper left and lower right panel, the three lines overlap each other also lower left panel's line have stable movement, and its value was close to one.

\section{Beta1}
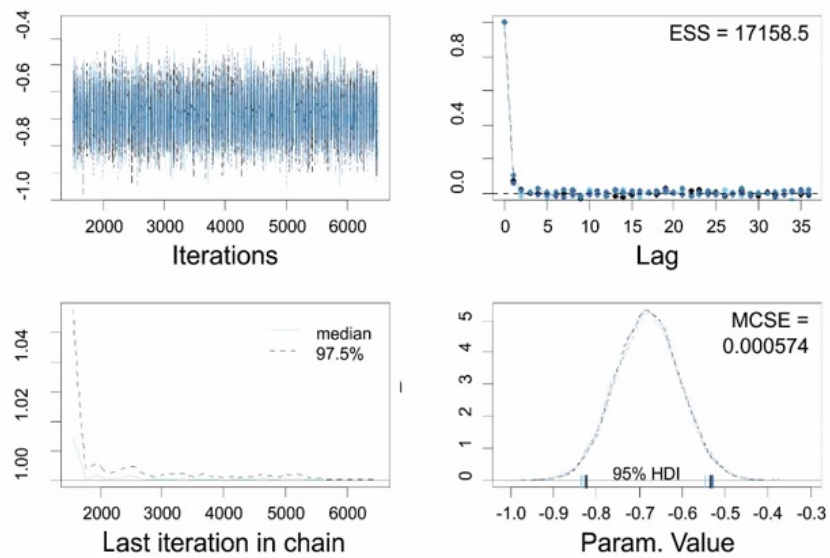

Figure 1

Iteration process

The results of the MCMC simulation presented in the diagram consisted of the highest density interval (HDI). HDI determines where are the densest range in the posterior probability distribution (Kruschke, 2015). Ninety-five percent of HDI used to conclude the presented result. Kruschke \& Liddell (2018) said the use of $95 \%$ HDI simply because of its familiarity with a $95 \%$ confidence interval in the frequentist method.

To assess null hypotheses, Kruschke (2015) suggested using a region of practical equivalence or ROPE. ROPE is a range of values that demonstrate null value equivalence (Kruschke, 2015). In this study, ROPE was set between -0.5 to 0 , considering information from the theoretical review stating a negative correlation between independent variables and addiction (Sayette \& Creswell, 2016). Therefore, the probability of posterior distribution density falls to zero or more is small. 

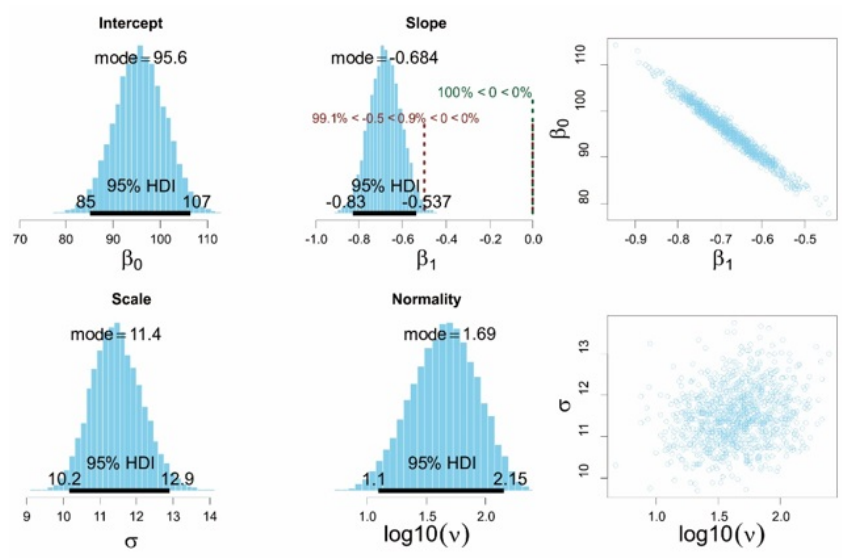

Figure 2

Bayesian regression

According to Kruschke (2015), we can assess whether the null value is rejected or otherwise by observe $95 \%$ HDI. If it falls entirely outside the ROPE, then the null hypothesis is rejected. Figure 1 illustrates posterior distribution due to the MCMC simulation chain and ROPE range value and HDI. The middle panel on Figure 2 portrays that the null value rejected as the result of $95 \%$ of HDI fall completely outside ROPE $(-0.5-0)$. To put it briefly, the result describes that self-regulation influences smoking addiction (see scatterplots in Figure 3). In Figure 4 , the superimposed line illustrates the posterior predictive regression line, while the vertical line shows smoking addiction probability when selfregulation equals "x." For instance, if the selfregulation score is 70 , then $95 \%$ predicted posterior distribution of smoking addiction falls within the $25-71.5$ range (see Figure 4).

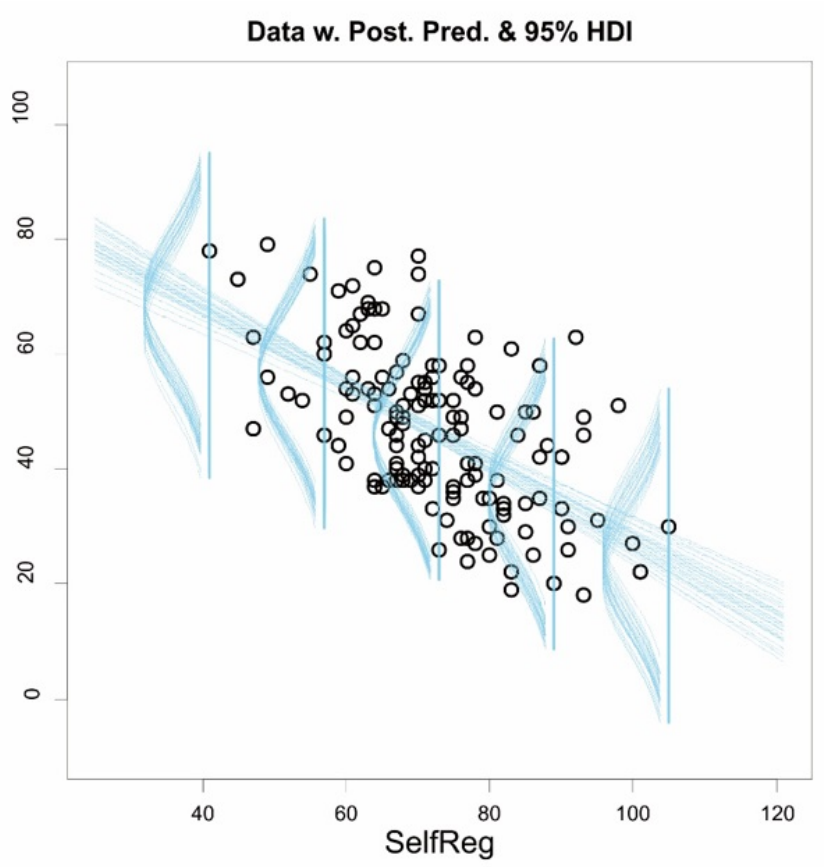

Figure 3

Bayesian scatterplot between smoking addiction and self-regulation

\section{Posterior Predicted $\mathrm{y}$ for $\mathrm{x}=70$}

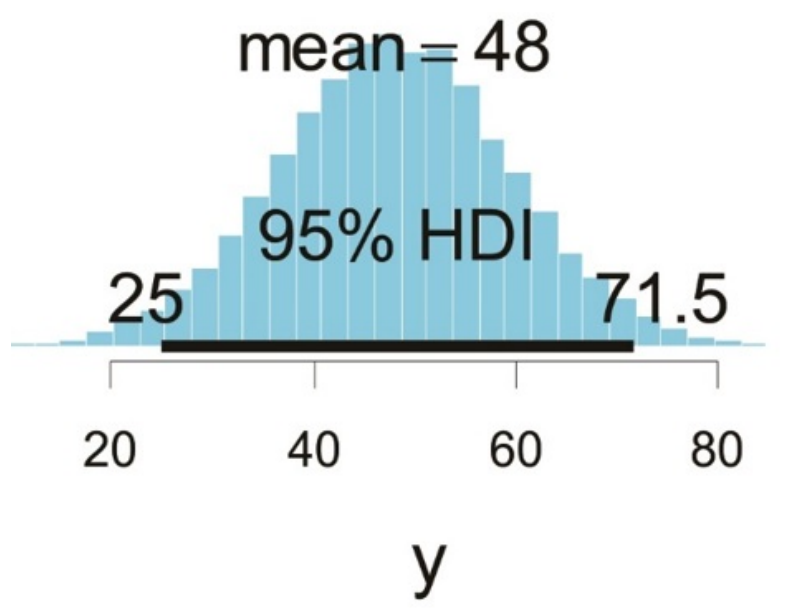

Figure 4

Smoking addiction prediction score for self-regulation $=$ 70 


\section{Linear regression}

Linear regression analysis was conducted to determine if their self-regulation can predict subjects' smoking addiction. The null hypothesis tested was that the regression coefficient is equivalent to 0 (zero). Violation of assumption test was conducted. There was not any missing data. The linearity test result also did not find any violation, as both variable data had a significance value below 0.05 and an insignificant deviation from linearity value $(p>0.05)$. The next assumption test was Shapiro-Wilk to assess the data's normality. Result shows dependent variable data is normal $(S W=0.987, d f=155$, $p=0.162)$ with skewness (0.121) and kurtosis $(-0.524)$.

The result showed that the variability of smoking addiction score was predicted by selfregulation $(F(1.153)=82.122, p<0$, with adjusted $r$ square $\left(R^{2}\right)$ of 0.345 . In other words, the self-regulation score is a good predictor of smoking addiction score.

\section{Discussion}

This study aimed to determine the relation between self-regulation and smoking addiction in adolescents, especially high school students. Results from both analysis methods showed a significant negative correlation between selfregulation and smoking addiction. This result is consistent with Sayette and Creswell (2016), who stated that addictive behavior is caused by self-regulation failure. In the addictive state, an adolescent unlikely to regulate nor control his emotion, behavior, and mind (Faulkner et al., 2020).

Sayette and Crewell (2016) argue that there are two models of self-regulation failure, misregulation and under-regulation. Misregulation refers to a wrong belief or method when regulating one behavior. For example, a teenager is convinced that smoking led to mood improvement and emotional serenity. Based on this conviction, they use smoking to regulate negative moods. They believe that their mood and emotion can be modified by smoking a cigarette. Nevertheless, a study found that when one considers that their negative mood is unchangeable, then the temptation to do impulse behavior (e.g., smoking) will be reduced (Tice et al., 2001).

The second model of regulation failure is under-regulation. Many self-regulation failures are conceived as under-regulation because it refers to the inability to show self-regulation aspects, either part or all of it. These incapacities led to blunder in regulating his behaviors. This leads to the inability to regulate the impulse (Baumeister et al., 1994).

Commonly, when adolescents develop smoking behavior, they suffer under-regulation, specifically to set a goal. They tend to have trouble selecting behavioral standards. The effect is that when the situation changes, their behavior is easily influenced by external variables. This case will lead to self-regulation failure because it is difficult, even impossible, to regulate anything when one has no standard or goal for their behavior (Baumeister et al., 1994). Inability to set a standard also impacts another self-regulation aspect, that is, monitoring an individual competence to supervise his behaviors.

Adolescent smokers who lack monitoring skill is likely to bring a conflict to themselves and their surroundings. Conflict is one of smoking addiction's aspects: the discrepancy between a smoker's behaviors and another activity, environment, or himself as a personal (Griffiths, 2005; Rosenberg \& Feder, 2014). Even though this conflict causes many drawbacks for them and they have been recognized and aware of it, they continue to smoke because they cannot regulate themselves to cease smoking. For instance, even a lack of money will not stop them from finding cigarettes (e.g., asking their friend for cigarettes or cash; or even stealing to buy cigarettes). It can be understood since addictive teenagers also lack inhibition ability.

Ogden (2005) stated that a person who is addicted fails to resist an urge or temptation. Meanwhile, to be well regulated, someone must possess inhibition skills (Coulacoglou \& 
Saklofske, 2017). Barkley (1997, 2001) argued that the main requirement in the self-regulation process is behavioral inhibition. Behavioral inhibition hampers behavior impulse and brings out productive behaviors even when it is undesirable. Without inhibition skills, someone will be prone to impulsive behaviors (Nigg, 2017) such as smoking addiction. The lack of inhibition also explains why adolescent smokers have difficulties when they want to stop (Hatzigeorgiadis et al., 2016).

Besides self-regulation, other variables influence smoking addiction. Regression analysis showed that $34 \%$ of the variance in smoking addiction score is explained by self-regulation while other variables influence the rest. The most studied variable correlated to smoking addiction is nicotine as the main substance in the cigarette. It is because nicotine affected smokers' brain and promote dependency (Faulkner et al., 2020). Another variable related to smoking addiction is the social factor. Smoking had been proven correlated to social awareness, social skills (Albert-Lőrincz et al., 2020), social desirability (Messeri et al., 2019), gender (Cui et al., 2018; Kodriati et al., 2018), and peer-group choice (Liu et al., 2017). Abe et al. (2019), Choi et al. (2017) also stated that personality factors influence the smoking dependence process. Even, Erzurumluoglu et al. (2020) found that genetic variation has a role in smoking behavior development. They argued that some individuals are more sensitive to cigarette dependence than others. Nevertheless, the environment remains a dominant influence on smokers. A study found teens more at risk of smoking if their parents and siblings are smokers (Andrade et al., 2017).

Students need to develop self-regulation ability because it is needed to prevent them from smoking. Besides, increasing self-regulation ability will help the smoking cessation process (Hatzigeorgiadis et al., 2016). Despite physical treatment, improving psychological skills, such as self-regulation and motivation, is an essential stage in the smoking cessation process (Biber \& Ellis, 2017).

The generalisability of the results of this study is subject to certain limitations. The sample used in this study was three schools in the Sleman district; therefore, the generalisability of the results is limited to these schools only. Further studies should include more schools and more districts to understand the effects of self-regulation on smoking addiction among adolescents.

\section{References}

Abe, S., Oshio, A., Kawamoto, T., Ito, H., Hirashima, T., Tsubota, Y., \& Tani, I. (2019). Smokers are extraverted in Japan: Smoking habit and the big five personality traits: SAGE Open, 9(3), 1-6. https://doi.or g/10.1177/2158244019859956

Albert-Lőrincz, E., Paulik, E., Szabo, B., Foley, K., \& Gasparik, A. I. (2020). Adolescent smoking and the social capital of local communities in three counties in Romania. Gaceta Sanitaria, 33(6), 547-553. https://do i.org/10.1016/j.gaceta.2018.05.009

Andrade, R. C. C. de, Ferreira, A. D., Ramos, D., Ramos, E. M. C., Scarabottolo, C. C., Saraiva, B. T. C., Gobbo, L. A., \& Christofaro, D. G. D. (2017). Smoking among adolescents is associated with their own characteristics and with parental smoking: Cross-sectional study. Sao Paulo Medical Journal, 135(6), 561-567. https://doi.org/10.1590/1516-318 0.2017 .0154220717

Baldwin, S. A., \& Larson, M. J. (2016). An introduction to using Bayesian linear regression with clinical data. Behaviour Research and Therapy, 98, 58-75. https://do i.org/10.1016/j.brat.2016.12.016

Baltes, P. B. (1997). On the incomplete architecture of human ontogeny: Selection, optimization, and compensation as foundation of developmental theory. American Psychologist, 52 (4), 366-380. http s://doi.org/10.1037/0003-066X.52.4.366

Barkley, R. A. (1997). Behavioral inhibition, sustained attention, and executive functions: Constructing a unifying theory of ADHD. Psychological Bulletin, 121(1), 
65-94. https://doi.org/10.1037/0033-2909. 121.1.65

Barkley, R. A. (2001). The executive functions and self-regulation: An evolutionary neuropsychological perspective. Neuropsychology Review, 11 (1), 1-29. https://doi.org/10.1023/a:100908541 7776

Barkley, R. A. (2012). The important role of executive functioning and self-regulation in ADHD. Guilford Publication. http://www.russellbarkley.org/ factsheets/ADHD_EF_and_SR.pdf

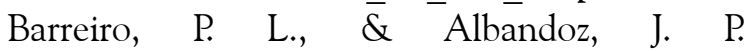 (2001). Population and sample. Sampling techniques. http://humanities.mn/fileman/U ploads/MD_handbook/sampling_en.pdf

Baumeister, R. F., Heatherton, T. F., \& Tice, D. M. (1994). Losing control: How and why people fail at self-regulation (Vol. 9). Academic Press.

Baumeister, R. F., \& Vohs, K. D. (2007). Selfregulation, ego depletion, and motivation. Social and Personality Psychology Compass, 1(1), 115-128. https://doi.org/10.1111/j.17 51-9004.2007.00001.x

Berkman, E. T. (2016). Self\# regulation training. In K. D. Vohs \& R. F. Baumeister (Eds.), Handbook of self-regulation (pp. 440-457). Guilford Publications.

Biber, D. D., \& Ellis, R. (2017). The effect of selfcompassion on the self-regulation of health behaviors: A systematic review: Journal of Health Psychology, 24(14), 260-2071. https: //doi.org/10.1177/1359105317713361

Billen, E., Garofalo, C., Weller, J. A., Kirisci, L., Reynolds, M., Tarter, R. E., \& Bogaerts, S. (2020). Bidirectional associations between self-regulation and deviance from adolescence to adulthood. Development and Psychopathology, 2020, 1-10. https://doi.org/10.1017/S0954579420 000656

Carey, F. R., \& Wilkinson, A. V. (2016). The biology of nicotine addiction and factors that differentiate youth who smoke from those who do not. In A. C. Swann, F. G. Moeller, \& M. Lijffijt (Eds.), Neurobiology of addictions (pp. 67-86). Oxford University Press.

Choi, J.-S., Payne, T. J., Ma, J. Z., \& Li, M. D. (2017). Relationship between personality traits and nicotine dependence in male and female smokers of African-American and European-American samples. Frontiers in Psychiatry, 8, 1-8. https://doi.org/10.3389/fp syt.2017.00122

Coulacoglou, C., \& Saklofske, D. H. (2017). Executive function, theory of mind, and adaptive behavior. In C. Coulacoglou \& D. H. Saklofske (Eds.), Psychometrics and psychological assessment (pp. 91-130). Academic Press. https://doi.org/10.1016/B9 78-0-12-802219-1.00005-5

Cui, Y., Zhu, Q., Lou, C., Gao, E., Cheng, Y., Zabin, L. S., \& Emerson, M. R. (2018). Gender differences in cigarette smoking and alcohol drinking among adolescents and young adults in Hanoi, Shanghai, and Taipei: Journal of International Medical Research, 46(12), 5257-5268. https://doi.or g/10.1177/0300060518807292

Daly, M., Delaney, L., \& Baumeister, R. F. (2015). Self-control, future orientation, smoking, and the impact of Dutch tobacco control measures. Addictive Behaviors Reports, 1, 89-96. https://doi.org/10.1016/j.abrep.2015 .07 .002

Deolia, S., Agarwal, S., Chhabra, K. G., Daphle, G., Sen, S., \& Jaiswal, A. (2018). Physical and psychological dependence of smokeless and smoked tobacco. Journal of Clinical and Diagnostic Research, 12(3), zc01-zc04. https://doi.org/10.7860/JCDR/2 018/28583.11233

Eisenberg, N., Smith, C. L., \& Spinrad, T. L. (2016). Effortful control: Relations with emotion regulation, adjustment, and socialization in childhood. In K. D. Vohs \& R. F. Baumeister (Eds.), Handbook of self-regulation (pp. 263-284). Guilford Publications. https://dialnet.unirioja.es/ser vlet/libro? codigo $=791836$

Erzurumluoglu, A. M., Liu, M., Jackson, V. E., Barnes, D. R., Datta, G., Melbourne, C. A., Young, R., Batini, C., Surendran, 
P., Jiang, T., Daud Adnan, S., Afaq, S., Agrawal, A., Altmaier, E., Antoniou, A. C., Asselbergs, F. W., Baumbach, C., Bierut, L., Bertelsen, S., ... Howson, J. M. M. (2020). Meta-analysis of up to 622,409 individuals identifies 40 novel smoking behaviour associated genetic loci. Molecular Psychiatry, 25(10), 2392-2409. https://doi.o $\mathrm{rg} / 10.1038 / \mathrm{s} 41380-018-0313-0$

Evans, D. E., To, C. N., \& Ashare, R. L. (2018). The role of cognitive control in the selfregulation and reinforcement of smoking behavior. Nicotine \&3 Tobacco Research, 21 (6), 747-754. https://doi.org/10.1093/ntr /nty029

Farmawati, A., Marchelaona, R., \& Anindyah, D. S. (2017). Smoking cessation reduces ratio of total cholesterol/high density lipoprotein (HDL) cholesterol levels on adult people in Yogyakarta Special Region. Journal of the Medical Sciences, 49(1). https: //doi.org/10.19106/JMedSci004901201705

Faulkner, P., Dean, A. C., Ghahremani, D. G., \& London, E. D. (2020). Neural basis of smoking-related difficulties in emotion regulation. International Journal of Neuropsychopharmacology, 23(7), 409-416. https://doi.org/10.1093/ijnp/pyaa015

Griffiths, M. (2005). A 'components' model of addiction within a biopsychosocial framework. Journal of Substance Use, 10(4), 191-197. https://doi.org/10.1080/14659890 500114359

Hatzigeorgiadis, A., Pappa, V., Tsiami, A., Tzatzaki, T., Georgakouli, K., Zourbanos, N., Goudasa, M., Chatzisarantis, N., Theodorakis, Y. (2016). Self-regulation strategies may enhance the acute effect of exercise on smoking delay. Addictive Behaviors, 57, 35-37. https://doi.org/10.101 6/j.addbeh.2016.01.012

Heatherton, T. F., Kozlowski, L. T., Frecker, R. C., \& Fagerström, K. O. (1991). The Fagerström Test for Nicotine Dependence: A revision of the Fagerström Tolerance Questionnaire. British Journal of Addiction, 86(9), 1119-1127. https://doi.org/10.1111/j .1360-0443.1991.tb01879.x
Jarosz, A. F., \& Wiley, J. (2014). What Are the Odds? A Practical Guide to Computing and Reporting Bayes Factors. The Journal of Problem Solving, 7(1), 1-9. https://doi.org/1 0.7771/1932-6246.1167

Khan, R. J., Stewart, C. P., Davis, S. K., Harvey, D. J., \& Leistikow, B. N. (2015). The risk and burden of smoking related heart disease mortality among young people in the United States. Tobacco Induced Diseases, 13(1), 1-8. https://doi.org/10.1186/s12971015-0041-z

Kodriati, N., Pursell, L., \& Hayati, E. N. (2018). A scoping review of men, masculinities, and smoking behavior: The importance of settings. Global Health Action, 11(sup.3), 37-48. https://doi.org/10.1080/16549716.2 019.1589763

Kruschke, J. K. (2015). Doing Bayesian data analysis: A tutorial with R, JAGS, and Stan $\left(2^{\text {nd }}\right.$ ed.). Academic Press.

Kruschke, J. K., \& Liddell, T. M. (2018). Bayesian data analysis for newcomers. Psychonomic Bulletin E Review, 25, 155-177. https://doi. org/10.3758/s13423-017-1272-1

Liu, J., Zhao, S., Chen, X., Falk, E., \& Albarracín, D. (2017). The influence of peer behavior as a function of social and cultural closeness: A meta-analysis of normative influence on adolescent smoking initiation and continuation. Psychological Bulletin, 143(10), 1082-1115. https://doi.or g/10.1037/bul0000113

Messeri, P., Cantrell, J., Mowery, P., Bennett, M., Hair, E., \& Vallone, D. (2019). Examining differences in cigarette smoking prevalence among young adults across national surveillance surveys. PLOS ONE, 14(12), e0225312. https://doi.org/10.1371/ journal.pone.0225312

Nigg, J. T. (2017). Annual Research Review: On the relations among self-regulation, self-control, executive functioning, effortful control, cognitive control, impulsivity, risktaking, and inhibition for developmental psychopathology. Journal of Child Psychology and Psychiatry, and Allied Disciplines, 58(4), 
361-383. https://doi.org/10.1111/jcpp.1267 5

Ogden, J. (2005). Health psychology: A textbook (3rd ed.). Open University Press.

Ranjit, A., Buchwald, J., Latvala, A., Heikkilä, K., Tuulio-Henriksson, A., Rose, R. J., Kaprio, J., \& Korhonen, T. (2019). Predictive association of smoking with depressive symptoms: A longitudinal study of adolescent twins. Prevention Science, 20 (7), 1021-1030. https://doi.org/10.1007/s 11121-019-01020-6

Ribeiro, G. L. A., Clementino, M. A., Gomes, M. da N. C., Firmino, R. T., Siqueira, M. B. L. D., \& Granville-Garcia, A. F. (2013). Smoking, behavioral factors and familial environment: A population based study with Brazilian adolescents. Revista de Salud Pública, 15(3), 342-353. (adolescentes).

Robalino, J. D., \& Macy, M. (2018). Peer effects on adolescent smoking: Are popular teens more influential? PLOS ONE, 13(7), e0189360. https://doi.org/10.1371/journal. pone. 0189360

Robert, P.-O., Kuipers, M. A. G., Rathmann, K., Moor, I., Kinnunen, J. M., Rimpelä, A., Perelman, J., Federico, B., Richter, M., Kunst, A. E., \& Lorant, V. (2019). Academic performance and adolescent smoking in 6 European cities: The role of friendship ties. International Journal of Adolescence and Youth, 24(1), 125-135. https://doi.org/10.1080/02673843 .2018 .1475288

Rosenberg, K. P., \& Feder, L. C. (2014). An introduction to behavioral addictions. In Behavioral Addictions (pp. 1-17). Elsevier. http://linkinghub.elsevier.com/ret rieve/pii/B978012407724900001X

Sayette, M. A., \& Creswell, K. G. (2016). Selfregulatory failure and addiction. In K. D. Vohs \& R. F. Baumeister (Eds.), Handbook of self-regulation (pp. 505-521). Guilford Press.

Schane, R. E., Glantz, S. A., \& Ling, P. M. (2009). Nondaily and Social Smoking: An Increasingly Prevalent Pattern. Archives of Internal Medicine,
169(19), 1742-1744. https://doi.org/10.100 1/archinternmed.2009.315

Schmidt, H. D., Rupprecht, L. E., \& Addy, N. A. (2018). Neurobiological and neurophysiological mechanisms underlying nicotine seeking and smoking relapse. Complex Psychiatry, 4(4), 169-189. https://d oi.org/10.1159/000494799

Tice, D. M., Bratslavsky, E., \& Baumeister, R. F. (2001). Emotional distress regulation takes precedence over impulse control: If you feel bad, do it! Journal of Personality and Social Psychology, 80(1), 53-67. https://doi.org/10. 1037//0022-3514.80.1.53

van de Schoot, R., \& Depaoli, S. (2014). Bayesian analyses: Where to start and what to report. The European Health Psychologist, 16(4), 75-84. https://ehps.net/ehp/index.p hp/contents/article/view/ehp.v16.i2.p75

Wagenmakers, E.-J. (2007). A practical solution to the pervasive problems of $\mathrm{p}$ values. Psychonomic Bulletin \& Review, 14(5), 779-804. https://doi.org/10.3758/BF03194 105

Wells, C. S., \& Wollack, J. A. (2003). An instructor's guide to understanding test reliability. Testing \& Evaluation Services, University of Wisconsin.

World Health Organization (WHO). (2015). Global youth tobacco survey: Indonesia report. World Health Organization.

Zhang, Z., Hamagami, F, Lijuan Wang, L., Nesselroade, J. R., \& Grimm, K. J. (2007). Bayesian analysis of longitudinal data using growth curve models. International Journal of Behavioral Development, 31(4), 374-383. https://doi.org/10.1177/01650254 07077764

Zimmerman, B. J. (2000). Attaining selfregulation: A social cognitive perspective. In M. B. R. P. Zeidner (Ed.), Handbook of self-regulation (pp. 13-39). Academic Press. http://www.sciencedirect.com/scienc e/article/pii/B9780121098902500317

\section{Notes}

* Research article. 